\title{
IMUNOREATIVIDADE DE APTÂMEROS ENGENHEIRADOS IN SILICO CONTRA EPÍTOPO NEUTRALIZANTE DO VÍRUS ZIKA VIA TERMOFORESE EM MICROESCALA
}

\author{
Catarina Cataldi ${ }^{1 *}$, Carlos Cruz $^{2}$, Bruno Leite ${ }^{3}$, Isabelle Viana ${ }^{4}$, Roberto Lins ${ }^{5}$ \\ 1,2,3,4,5, Departamento de virologia, Fiocruz-PE \\ *catarinacatldi@hotmail.com
}

\section{RESUMO}

Postulamos que a identificação e caracterização de anticorpos neutralizantes de alta afinidade é uma etapa decisiva no desenvolvimento de estratégias eficientes visando a prevenção, diagnóstico e terapia frente a pandemias infectocontagiosas como a do vírus Zika (ZIKV). Uma vez que não há relatos de transmissão sexual relacionada a outros flavivírus, anticorpos de alta afinidade podem ser usados para detecção específica de ZIKV em sêmen com alta sensibilidade. Além disso, podem compor uma formulação vacinal visando ao bloqueio da replicação viral e consequente neutralização da infecção. Como alternativa ao isolamento de anticorpos humanos e desenvolvimento de hibridomas, os aptâmeros artificiais vem ganhando espaço por possibilitar a produção em larga escala, além da modulação da imunorreatividade e estabilidade estrutural destas proteínas. Neste projeto nós hipotetizamos que aptâmeros peptídicos desenvolvidos computacionalmente contra um epítopo de anticorpo neutralizante da proteína do Envelope de ZIKV é capaz de detectar a proteína alvo em amostras biológicas com alta afinidade, atuando de forma efetiva no bloqueio da infecção viral a nível celular. Três dos quatro aptâmeros peptídicos desenvolvidos foram expressos em sistema procarioto e purificados por cromatografia de afinidade com rendimento médio de $3,7 \mathrm{~g} / \mathrm{L}$. As imunorreatividades dos três aptâmeros até então produzidos, foram obtidas através de ensaios de termoforese em microescala, com constantes de afinidade na ordem de micromolar. Como atividades subsequentes, serão realizados ensaios de cultura celular para a verificação do potencial neutralizante dos aptâmeros desenvolvidos quanto à inibição de infecção celular por ZIKV. Com a finalização desse projeto, estaremos contribuindo para o desenvolvimento de estratégias de combate e prevenção da pandemia do ZIKV. 